\title{
ROLE OF RESISTANCE (YRS) GENES TO PUCCINIA STRIIFORMIS IN FIVE BREAD WHEAT CULTIVARS SUSCEPTIBLE AND VALIDATION BY MOLECULAR MARKERS IN ASSESSMENT OF RESISTANCE
}

\author{
A. M.A. Abu Aly' ${ }^{1}$ and Thanaa H. A. Abd El-Kreem² \\ 1-Wheat Disease Research Department, Institute of Plant \\ Pathology, ARC, Egypt. 2-Wheat Research Department, Field \\ Crops Research Institute, ARC, Egypt \\ E-mall:dr.abdelaziz_abualy@yahoo.com
}

\begin{abstract}
Wheat stripe rust, caused by Puccinia striiformis $f$. sp. tritici, is one of the most destructive diseases of wheat in the world. Emergence of new race of the pathogen in Egypt at last decades, spread of those races pose effect at to wheat production in Egypt, has required assemblage of a broad genetic base of resistance. Five ten crosses between $Y r 5$, Yr10 and Yr15 and each of Sids 12, Sids 13, Gemmeiza 10, Gemmeiza 11, and Sakha 93, were performed. Results indicated that the five varieties parents exhibited high susceptible reaction against stripe rust at seedling and adult stage, on the other hand monogenic lines exhibited high resistance. While crosses against stripe rust at seedling and adult stages proved that plant segregation F1 plants of the five ten crosses having Yr5, Yr10 and Yr15, were resistant and exhibited low stripe rust reaction $(0-0$, and 1$)$ at seedling stage and low stripe rust severity ranged between $(0,10 \mathrm{R}$ and $10 \mathrm{MR})$ at adult stage. The result of F2 plants reaction exhibited wide range of stripe rust reaction (0 to 9$)$ at seedling stage and severity ranged between ( 0 to $80 \mathrm{~S}$ ) at adult stage but the direction was in the side resistance and this confirmed the results of $\mathrm{F} 1$. This result confirmed the presence of resistant gene in the segregations of the resulted crosses and verified that a single dominant pair gene controls stripe rust resistance at adult stages. Resistance gene of the F2 was expression performance to resistance genes to $\operatorname{Yr}$ 5, $\operatorname{Yr} 10$ and $Y r$ 15, those tolerant to yellow rust introgressive lines could be widely used as donors of stability in practical selection of bread wheat. Using the molecular marker method, Yr10 In this study, we used the primer Xpsp3000 to identify markers linked to yellow rust resistance genes. In this respect, specific DNA segment of 52 individual of F2 have linked with primer Xpsp3000 260-bp band. The rest 18 individuals did not linked with the primer Xpsp3000. Segregation in F2 of individual which, reacted with the primer YrSTS/7, 8 and shown in this respect, specific DNA segment of 58 individual of F2 have linked with primer YrSTS/7, 8 439-bp band. The rest 21 individuals did not link with the primer YrSTS/7, 8. These markers provide an important tool to plant breeders for marker-aided wheat breeding and also for pyramiding resistance genes in the absence of distinguishable rust virulence's
\end{abstract}

Keywords: Triticum aestivum, stripe rust, Yr's genes, molecular markers 


\section{INTRODUCTION}

Stripe rust, caused by Puccinia striiformis $f$. sp. tritici, is one of the most important diseases of wheat in the world. In Egypt, stripe rust attacked most of the commercial wheat cultivars during 1968 to 1995, causing severe infection in North Delta area El-Daoudi et al. (1996). Stripe rust caused high loss in the production of most Egyptian wheat cultivar in the delta area during 1996/1997 growing seasons ElDaoudi, (1998). Identifying resistance genes in wheat varieties, even those overcome by new races of the yellow rust pathogen is important for a better understanding of race changes and a better use of various resistance genes with various strategies (Chen 2005). Gene pyramiding, gene deployment and multilane varieties were considered to be useful for prolonging race-specific resistance (Mclntosh and Lagudah 2000). There are a few of genes are effective in the seedling stage (Ma et al. 2001; Yan et al. 2003). Thus, it is very important to search to identify new resistance genes for wheat breeding programmes. Identification of yellow rust resistance genes and breeding of resistant varieties is an effective approach to minimizing wheat losses due to this disease. To date, more than 70 stripe rust resistance genes, officially or provisionally designated $\mathrm{Yr}$ for 'stripe rust', have been reported in wheat (Mclntosh et al., 2009; Chen 2005; Cheng and Chen 2010).

Yr5 was described first in 1966 by Macer in Triticum spelta album (Macer. 1966). Yr5 is located on chromosome arm 2BL, $21 \mathrm{cM}$ away from the centromere (Law. 1976). (Kema 1992) transferred this gene into some commercial cultivars. Gerechter-Amitai., et al 1970). reported that accession G-25 of Triticum dicoccoides Korn was resistant to many races of Puccinia striiformis from different geographical origins. (Gerechter-Amitai et al., 1974 and 1989) Later, it was shown that this stripe rust resistance was conferred by the dominant gene Yr15. (Mclntosh et al.,1996) showed that it is located on the short arm of chromosome 1B. Yr15 was introgressed into tetraploid and hexaploid wheats. With the use of molecular markers and a genetic linkage map, various wheat genes that control yellow rust resistance have been successfully tagged (Prasad et al. 2003). Identify potential molecular markers associated with yellow rust resistance in wheat. These markers shall be used for selecting yellow rust resistance in segregating populations. A number of genes affect yellow rust resistance in wheat. (McIntosh et al. 2005). Molecular markers have been linked to many yellow rust resistance genes in wheat, such as Yr5, Yr10, Yr15, Yr17, Yr24, Yr26, Yr29, Yr32, Yr34 and YrH52 (Chague et al. 1999; Robert et al. 2000; Peng et al. 2000; Sun et al. 2002; and Wang et al. 2008). These markers provide an 
important tool to plant breeders for marker-aided wheat breeding and also for pyramiding resistance genes in the absence of distinguishable rust virulence's (Kaur et al. 2008). In this study, we used these primer sets to identify markers linked to yellow rust resistance genes in wheat by bulk sergeant analysis. Here, we report the identification of Xgwm382 marker that is associated with yellow rust resistance and can potentially be used to select yellow rust resistant wheat germplasm. Molecular markers are relatively short sequences which can be specifically amplified by PCR and detected in the presence of all other genomic sequences whose location in the genome is mapped. These markers produce simple and reproducible patterns on agarose or poly-acrylamide gel. Some STS markers reported for $\mathrm{Yr}$ genes include YrSTS(7,8), YrSTS (Lagudah , 2011) and S19M93-140 for Yr5 (Chen. et. al 2003), Yr10 Smith et. al., 2003)

\section{MATERIALS AND METHODS}

The cultivars used in this study included i.e. Sids 12 , Sids 13 , Gemmeiza 10, Gemmeiza 11, and Sakha 93 exhibited a wide range of variability in their susceptibility to stripe rust, and known $Y r$ gene carrier monogenic lines, Yr5, Yr10 and Yr15 exhibited high level of resistance to stripe rust at adult stage under Egyptian condition. These parents were sown at Sakha station and Nubaria Agric. Res. Sta. Development of crosses and generations: From 2012-2013 to 20142015, five cultivars, as female parent, was crossed with known genes carrier lines (male parent), the seed was sown to get the F1 seeds and the F1 plants were self-pollinated to obtain F2 seeds.

\section{Infection assessment and statistical analysis}

Through the methods of classical genetics, allelic analysis, wheat yellow rust resistant genes were analyzed at seedling stage. Each cultivar, F1 and F2 were grown in standard peat soil in $10 \mathrm{~cm}$ square pots containing 10 plants. Seedlings at the two leaf stage when the first leaf was fully expelled were inoculated with Pst isolates (Stubbs, 1988). After inoculation, the seedlings were placed in a dew chamber at $10^{\circ} \mathrm{C}$ and $100 \%$ of relative humidity for $24 \mathrm{~h}$ and then transferred to greenhouse maintained with $16 \mathrm{~h}$ light/ $8 \mathrm{~h}$ dark photoperiod at 14-18 C. Infection type (IT) was recorded 15-17 days after inoculation when rust was fully developed on the susceptible check Morocco according to scale described by McNeal et al.. (1971). Based on the traditional 9 scale of infection types (IT), 4 classes were used in this study, the infection types i.e. 0,1 and 2 were resistant; 3, 4 and 5 types, moderate resistant; 6 and 7 moderate susceptible and 8 and 9 high susceptible. . The division standard to resistant and 
susceptible was adapted according to infection type levels and infection type number in the parents, F1 and F2 generation to determine resistant or susceptible Infection type (Liu, 1988).

Table 1: Name and pedigree bread wheat cultivar used in the study

\begin{tabular}{|l|l|l|c|}
\hline No & Genotypes & Pedigree & $\begin{array}{l}\text { Reaction to } \\
\text { yellow rust }\end{array}$ \\
\hline 1 & Sids 12 & $\begin{array}{l}\text { BUS//7C//ALD/5/MAYA74/ON//1160.147/3/B } \\
\text { B/GLL/4/CHAT"S"/6/MAYA/VUL//CMH74A.6 } \\
\text { 30/4*SX. SD720096-4SD-1SD-1SD-0SD. }\end{array}$ & Susceptible \\
\hline 2 & Sids 13 & $\begin{array}{l}\text { ALMAZ-19=KAUZ"S"//TSI/SNB"S". } \\
\text { ICW94-0375-4AP-2AP-030AP-0APS-3AP- } \\
\text { 0APS-050AP-0AP-0SD. }\end{array}$ & Susceptible \\
\hline 3 & $\begin{array}{l}\text { Gemmeiza } \\
10\end{array}$ & $\begin{array}{l}\text { MAYA 74 "S" / ON//1160 - 147/3/BB/GLL/4/ } \\
\text { CHAT "S" /5/ CROW "S" } \\
\text { CGM 5820 - 3GM - 1GM - 2GM - OGM }\end{array}$ & Susceptible \\
\hline 4 & $\begin{array}{l}\text { Gemmeiza } \\
11\end{array}$ & $\begin{array}{l}\text { BOW"S"/KVZ"S"//7C/SER182/3/GIZA } \\
\text { 168/SAKHA61. } \\
\text { GM7892-2GM-1GM-2GM-1GM-0GM. }\end{array}$ & Susceptible \\
\hline 5 & Sakha 93 & $\begin{array}{l}\text { Sakha 92/ TR 810328 } \\
\text { S 8871-1S-2S-1S-0S }\end{array}$ & Susceptible \\
\hline 6 & Yr5 & & Resistant \\
\hline 7 & Yr10 & & Resistant \\
\hline 8 & Yr15 & & Resistant \\
\hline
\end{tabular}

Chi-square $(\mathrm{X} 2)$ and corresponding probability $(\mathrm{P})$ values were used to evaluate the goodness of fit of the observed and expected segregation ratios of $\mathrm{F} 2$ populations. At the adult tests under field condition was restricted in the spreader plants which were using artificial infection to stripe rust races. Inoculums is virulent for $Y r 2, Y r 6$, Yr7, Yr8, Yr9, Yr11, Yr12, Yr17, Yr18, Yr27and a virulent for Yr5, Yr10, Yr15, YrSP gen. All materials were inoculated at seedling and adult, were considered as the susceptible ones. To clarify, mode of inheritance of expected ratio of the phenotypes classes of the stripe rust, infection types were determined using (X2) analysis according to the method of Steel and Torrie (1960).

\section{DNA extraction procedure}

Total DNA of each wheat cultivar and isogenic line was extracted from $60 \mathrm{mg}$ leaf tissue which digested in liquid nitrogen with a mortar and pestle using i-genomic plant DNA extraction Mini Kit (iNtRON Biotechnology, Inc, Cat. No. 17371) according to manufacturer's instructions. The eluted DNA was stored at -20 .

Polymerase chain reaction was performed in a thermocycler according to the conditions in Table (2). Following the amplification, $2 \mu \mathrm{l}$ loading buffer was mixed with $5 \mu$ PCR product that ran on $1 \%$ agarose gel in $1 \mathrm{x}$ TBE buffer at $85 \mathrm{~V}$ for two hours and the bands were observed 
under UV light. The gels were stained using ethidium bromide and either Gene Ruler 100 bp DNA Ladder Plus (Fermentas, Germany) was used as a molecular weight marker. The products of primer YrSTS7/8 did not separate on $1 \%$ agarose and therefore were analyzed by PolyAcrylamide Gel Electrophoresis (PAGE) on a denaturing 6\% gel at 200 Vfor 5 hours. Band patterns were visualized using silver staining (Chen et al. 2003) and images were captured by a scanner.

Table 2: Sequences of markers used to identify yellow rust resistance genes

\begin{tabular}{|c|l|l|l|}
\hline Gene & Marker & \multicolumn{1}{|c|}{ Primer Sequence } & \multicolumn{1}{|c|}{ Reference } \\
\hline Yr10 & Xpsp3000 & F:GCAGACCTGTGTCATTGGTC & $\begin{array}{l}\text { Bariana et al. } \\
\text { R:GATATAGTGGCAGCAGGATACG }\end{array}$ \\
& & (2002) \\
\hline Yr5 & YrSTS $(7,8)$ & $\begin{array}{l}\text { F:GTACAATTCACCTAGAGT } \\
\text { R:GCAAGTTTTCTCCCTATT }\end{array}$ & $\begin{array}{l}\text { Chen et al. } \\
(2003)\end{array}$ \\
\hline
\end{tabular}

Table 3: PCR conditions used for each primer*

\begin{tabular}{|l|l|l|l|l|l|l|}
\hline Primer & $\begin{array}{l}\text { Initial } \\
\text { Denaturation }\end{array}$ & $\begin{array}{l}\text { Number } \\
\text { of } \\
\text { cycles }\end{array}$ & Enaturation & Annealing $^{\star \star \star}$ & Extension $^{\star \star \star}$ & $\begin{array}{l}\text { Final } \\
\text { Extension }^{\star \star}\end{array}$ \\
\hline YrSTS7/8 & $94(3)$ & 30 & $94(60)$ & $60(30)$ & $72(120)$ & $72(10)$ \\
\hline Xpsp3000 & $94(3)$ & 30 & $94(60)$ & $60(30)$ & & $72(10)$ \\
\hline
\end{tabular}

* The numbers before the parentheses indicate temperature 'ㅇ'.; ${ }^{* *}$ The numbers in the parentheses indicate initial denaturation and final extension in minutes; ${ }^{* *}$ The numbers in the parentheses show duration of each step in seconds

\section{RESULTS}

Evaluation of the tested wheat monogenic lines, F1 hybrids and F2 against stripe rust at seedling and adult stages:

Data in Table (3) reveal the distribution of infection type, of parents, and $\mathrm{F} 1$ hybrids for the five ten crosses having Yr5, Yr10 and Yr15. In this respect, Sids-12, Sids-13, Gemmeiza-10, Gemmeiza-11, and Sakha-93 exhibited high susceptibility infection type ranged between 7-9. Meanwhile, the monogenic lines Yr5, Yr10 and Yr15 exhibited infection type $0,-1$. As for $\mathrm{F} 1$ plants of the five ten tested crosses, all plants exhibited low infection type ranged between $0,-2$ (resistance), this result revealed that resistance was dominant over susceptibility in these crosses in F1 stage 
Table 4: Response of three wheat monogenic lines, five cultivars and F1 hybrids against stripe rust infection type using race $134 \mathrm{E} 158$ at seedling stage

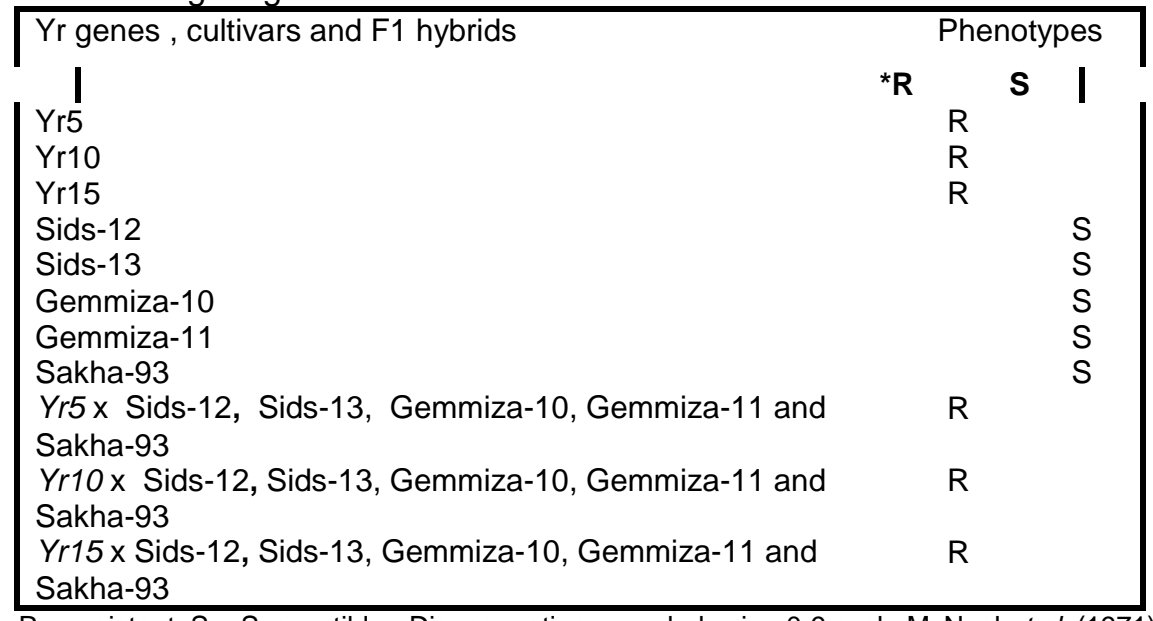

$\mathrm{R}=$ resistant, $\mathrm{S}=$ Susceptible - Disease rating recorded using 0-9 scale McNeal et al. (1971)

Table 5: Evaluation of crosses of the five cvs. having resistant Yr's genes against stripe rust infection using race 134E158 at seedling stage

\begin{tabular}{|c|c|c|c|c|c|c|}
\hline \multirow[t]{2}{*}{ Crosses } & \multirow[t]{2}{*}{$\begin{array}{l}\text { Number } \\
\text { of } \\
\text { F2 plant }\end{array}$} & \multicolumn{2}{|c|}{$\begin{array}{l}\text { Phenotypes } \\
\text { (observed } \\
\text { Ratio) }\end{array}$} & \multirow[t]{2}{*}{$\begin{array}{l}\text { Expected } \\
\text { Ratio }\end{array}$} & \multirow[t]{2}{*}{$x^{2}$} & \multirow[t]{2}{*}{ P.value } \\
\hline & & $\mathbf{R}$ & $\mathbf{S}$ & & & \\
\hline Yr5 x Sids -12 & 135 & 94 & 41 & $3: 1$ & 2.08 & $0.25-0.1$ \\
\hline Yr5 $\times$ Sids -13 & 192 & 143 & 49 & $3: 1$ & 0.03 & $0.9-0.75$ \\
\hline $\begin{array}{l}\text { Yr5x } \\
\text { Gemmeiza-10 }\end{array}$ & 175 & 130 & 45 & $3: 1$ & 0.05 & $0.9-0.75$ \\
\hline $\begin{array}{l}\text { Yr5x } \\
\text { Gemmeiza-11 }\end{array}$ & 121 & 90 & 31 & $3: 1$ & 0.03 & $0.9-0.75$ \\
\hline Yr5x Sakha-93 & 143 & 105 & 38 & $3: 1$ & 0.19 & $0.75-0.5$ \\
\hline Yr10 x Sids-12 & 147 & 108 & 39 & $3: 1$ & 0.18 & $0.75-0.5$ \\
\hline Yr10 x Sids-13 & 180 & 141 & 39 & $3: 1$ & 0.11 & $0.75-0.5$ \\
\hline $\begin{array}{l}\text { Yr10 x } \\
\text { Gemmeiza-10 }\end{array}$ & 198 & 153 & 45 & $3: 1$ & 0.55 & $0.75-0.5$ \\
\hline $\begin{array}{ll}\text { Yr10 } & \mathrm{x} \\
\text { Gemmeiza-11 } & \end{array}$ & 143 & 101 & 42 & $3: 1$ & 1.46 & $0.25-0.1$ \\
\hline $\begin{array}{l}\text { Yr10 x Sakha- } \\
93\end{array}$ & 180 & 140 & 40 & $3: 1$ & 0.74 & $0.75-0.5$ \\
\hline Yr15 $\times$ Sids-12 & 150 & 105 & 45 & $3: 1$ & 2.00 & $0.25-0.1$ \\
\hline Yr15 $\times$ Sids -13 & 190 & 145 & 45 & $3: 1$ & 0.18 & $0.75-0.5$ \\
\hline $\begin{array}{l}\text { Yr15 x } \\
\text { Gemmeiza-10 }\end{array}$ & 163 & 118 & 45 & $3: 1$ & 0.59 & $0.75-0.5$ \\
\hline $\begin{array}{ll}\text { Yr15 } & x \\
\text { Gemmeiza-11 }\end{array}$ & 140 & 118 & 22 & $13: 3$ & 0.847 & $0.75-0.5$ \\
\hline $\begin{array}{l}\text { Yr15 x Sakha- } \\
93\end{array}$ & 120 & 83 & 37 & $3: 1$ & 2.18 & $0.25-0.1$ \\
\hline
\end{tabular}


Results presented in Table (4) showed that segregated phenotypes F2 plants of the crosses between Yr5, Yr10 and Yr15 and the wheat varieties Sids 12, Sids 13 ,Gemmeiza 10, and Sakha 93 the resistance was dominant over susceptibility in these crosses, with expected ratio $3: 1$. This $3: 1$ ratio verified that single dominant gene pair controls resistance and supported the fact that Yr5, Yr10 and Yr15 carried the seedling stage, while the cross Yr15 x Gemmeiza-11 number of resistant and susceptible plants were 118 and 22, respectively. These frequencies fitted the theoretical expected ratio of 13: 3 with $P$ value $0.5-0.25$ indicated that presence of one dominant gene RR causing resistance against yellow rust, in the absence of an other dominant gene, which interacted with it to cause susceptibility by inhibiting the effect of the resistance gene

Data in Table (5) showed that, the wheat monogenic lines Yr5, Y10 and Yr15 were completely resistant reaction. Showed zero percent final rust severity compared with the other tested monogenic lines which showed final rust severity ranged from 0 to TrR. While, the tested wheat cultivars i.e. Sids 12, Sids 13 ,Gemmeiza 10, Gemmeiza 11 and Sakha 93 showed all of five parents exhibited high susceptibility, where stripe rust severity (\%) ranged between (10MS-80S) during the three seasons. As for as $F_{1}$ plant of the five ten tested crosses exhibited high resistance where their stripe rust severity. (\%) ranged between 0 and $5 R$ these results revealed that resistance was dominant over susceptibility in these crosses in $F_{1}$ at adult stage in Table (6).

Table 6: Final stripe rust severity of three wheat monogenic lines and five cultivars at adult plant stage at Sakha station during three successive growing seasons (2012/13 - 2014/15)

Yrgenes and

cultivars

Yr5

Yr10

Yr15

Sids 12

Sids 13

Gemmiza 10

Gemmiza 11

Sakha 93

\section{Season / rust severity}

2013/14

2014/15

\begin{tabular}{lll}
0 & 0 & 0 \\
0 & 0 & TrR \\
0 & 0 & 0 \\
$30 \mathrm{~S}$ & $40 \mathrm{~S}$ & $80 \mathrm{~S}$ \\
$20 \mathrm{~S}$ & $30 \mathrm{~S}$ & $70 \mathrm{~S}$ \\
$10 \mathrm{MS}$ & $10 \mathrm{MS}$ & $30 \mathrm{~S}$ \\
$10 \mathrm{MS}$ & $10 \mathrm{MS}$ & $40 \mathrm{~S}$ \\
$30 \mathrm{~S}$ & $30 \mathrm{~S}$ & $80 \mathrm{~S}$ \\
\hline
\end{tabular}


Table 7: Inheritance of yellow rust resistance in F1 hybrids obtained by the crossing of resistance genes $\mathrm{Yr}$ 5, $\mathrm{Yr} 10$ and $\mathrm{Yr} 15$ with five Egyptian cultivars under filed condition

\begin{tabular}{|c|c|c|c|}
\hline \multirow[t]{2}{*}{ F1 hybrids } & \multirow{2}{*}{$\begin{array}{l}\text { No .of } \\
\text { plants } \\
\text { under } \\
\text { study }\end{array}$} & \multicolumn{2}{|c|}{$\begin{array}{l}\text { Ratio of resistant and } \\
\text { susceptible plants }\end{array}$} \\
\hline & & $\mathbf{R}$ & $\mathrm{S}$ \\
\hline $\begin{array}{l}\text { Yr5 x (Sids-12, Sids-13, Gemmiza- } \\
\text { 10, Gemmiza-11 and Sakha-93) }\end{array}$ & 150 & 150 & - \\
\hline $\begin{array}{l}\text { Yr10 x (Sids-12, Sids-13, Gemmiza- } \\
\text { 10, Gemmiza-11 and Sakha-93) }\end{array}$ & 165 & 165 & - \\
\hline $\begin{array}{l}\text { Yr15 x ( Sids-12, Sids-13, Gemmiza- } \\
\text { 10, Gemmiza-11 and Sakha-93) }\end{array}$ & 150 & 150 & - \\
\hline
\end{tabular}

The infection type frequency distribution and the disease severity class of the F2 populations of each of the five ten crosses were performed. Inoculation was accomplished by using a mixture of the most prevalent races in the area at adult stage.

Data presented in Table(7) the obtained results derived from F2 of the five ten tested crosses having resistance genes exhibited a wide range of reaction to stripe rust severity ranged between 0-80S. The segregated phenotypes showed that F2 plants of the crosses between Yr5, Yr10 and Yr15 and the wheat varieties Sids- 12, Sids13, Gemmeiza-10, Gemmeiza-11 and Sakha-93 were as follow, (96R:32S, 102R:45S, 124R:30S, 153R:54S and 146R:51S), (131R:40S, 120R:46S, 1161R:53S, 101R:42S and 102R:30S) and (166R:49S, 168R:61S, 120R:46S, 98R:47S and 125R:46S), respectively, with expected ratio $3: 1$. This $3: 1$ ratio verified that single dominant gene pair controls resistance and supported the fact that Yr5, Yr10 and Yr15 carried the seedling and adult plant resistance gene and showed gene expression of resistance to stripe rust in all tested crosses at adult

Table 8: Evaluation of crosses of the five wheat cvs. having resistant genes (Yr's) against stripe rust infection using a mixture races at adult stage

\begin{tabular}{|l|c|c|c|c|c|c|}
\hline \multicolumn{1}{|c|}{ Crosses } & $\begin{array}{l}\text { Number } \\
\text { of F2 } \\
\text { plant }\end{array}$ & $\begin{array}{c}\text { Phenotypes } \\
\text { (observed } \\
\text { Ratio) }\end{array}$ & $\begin{array}{l}\text { Expected } \\
\text { Ratio }\end{array}$ & $\mathbf{X}^{\mathbf{2}}$ & P.value \\
\cline { 3 - 6 } & $\mathbf{R}$ & $\mathbf{S}$ & & & \\
\hline Yr5x Sids-12 & 128 & 96 & 32 & $\mathbf{3}: \mathbf{1}$ & 0.00 & $\mathbf{1 0 0}$ \\
\hline Yr5 Sids-13 & 147 & 102 & 45 & $\mathbf{3}: \mathbf{1}$ & 2.469 & $\mathbf{0 . 2 5 - 0 . 1}$ \\
\hline $\begin{array}{l}\text { Yr5x } \\
\text { Gemmeiza-10 }\end{array}$ & 154 & 124 & 30 & $\mathbf{3}: \mathbf{1}$ & 2.502 & $\mathbf{0 . 2 5 - 0 . 1}$ \\
\hline $\begin{array}{l}\text { Yr5x } \\
\text { Gemmieza-11 }\end{array}$ & 207 & 153 & 54 & $\mathbf{3}: \mathbf{1}$ & 0.130 & $\mathbf{0 . 5 - 0 . 2 5}$ \\
\hline Yr5x Sakha- & 197 & 146 & 51 & $\mathbf{3}: \mathbf{1}$ & 0.083 & $\mathbf{0 . 9 - 0 . 7 5}$ \\
\hline
\end{tabular}




\begin{tabular}{|c|c|c|c|c|c|c|}
\hline 93 & & & & & & \\
\hline Yr10 $\times$ Sids-12 & 171 & 131 & 40 & $3: 1$ & 0.236 & $0.5-0.25$ \\
\hline Yr10 $\times$ Sids-13 & 166 & 120 & 46 & $3: 1$ & 0.651 & $0.5-0.25$ \\
\hline $\begin{array}{l}\text { Yr10 x } \\
\text { Gemmeiza-10 }\end{array}$ & 214 & 161 & 53 & $3: 1$ & 0.006 & $\begin{array}{l}0.99- \\
0.95\end{array}$ \\
\hline $\begin{array}{l}\text { Yr10x } \\
\text { Gemmeiza-11 }\end{array}$ & 143 & 101 & 42 & $3: 1$ & 1.457 & $0.25-0.1$ \\
\hline $\begin{array}{l}\text { Yr10 x Sakha- } \\
93\end{array}$ & 132 & 102 & 30 & $3: 1$ & 0.364 & $0.5-0.25$ \\
\hline Yr15 x Sids-12 & 215 & 166 & 49 & $3: 1$ & 0.560 & $0.5-0.25$ \\
\hline Yr15 x Sids-13 & 229 & 168 & 61 & $3: 1$ & 0.328 & $0.5-0.25$ \\
\hline $\begin{array}{l}\text { Yr15 x } \\
\text { Gemmeiza-10 }\end{array}$ & 166 & 120 & 46 & $3: 1$ & 0.651 & $0.5-0.25$ \\
\hline $\begin{array}{l}\text { Yr15 x } \\
\text { Gemmeiza-11 }\end{array}$ & 145 & 98 & 47 & $3: 1$ & 4.251 & $\begin{array}{l}0.05- \\
0.01\end{array}$ \\
\hline $\begin{array}{l}\text { Yr15 x Sakha- } \\
93\end{array}$ & 171 & 125 & 46 & $3: 1$ & 0.329 & $0.5-0.25$ \\
\hline
\end{tabular}
M S
$\mathbf{R}$
$\mathbf{R} \quad \mathbf{R}$
S
S
$\mathbf{R}$
S S
$\mathbf{R}$
$\mathbf{R} \quad \mathbf{R} \quad \mathbf{R}$

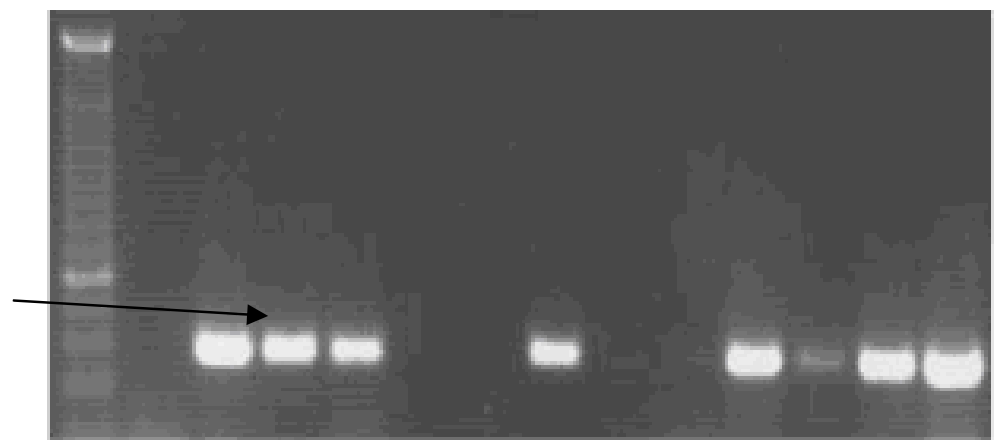

$\mathrm{R}=$ resistance

$\mathrm{S}=$ susceptibile

Figure 1: Amplification with marker Xpsp3000 produced 260-bp fragment in

F2 resistance segregation carrier gene Yr10

\section{Marker for Yrs gene}

Stripe rust resistance gene $Y r 10$ is race-specific, and was mapped on chromosome 2BS of wheat. The available marker Xpsp3000, for Yr10. The results PCR amplification with marker Xpsp3000 produced 260-bp fragment in F2 resistance segregation carry gene Yr10 and did not show any amplification in F2 susceptible segregation not carry gene Yr10 (figure 1). Segregation in F2 of Yr10x Sids 12 individual which, reacted with the primer Xpsp3000 and shown in fig(1) in this respect, specific DNA segment of 52 individual of F2 
have linked with primer Xpsp3000 260-bp band. The rest 18 individuals did not linked with the primer Xpsp3000. this result reveled that the resistance: susceptible individuals are 52:18 with expected ratio $3: 1$ which verified by $X^{2}$. The results of current study suggest that transfer by crosses Yr10 could be one of the genes responsible for the resistance.

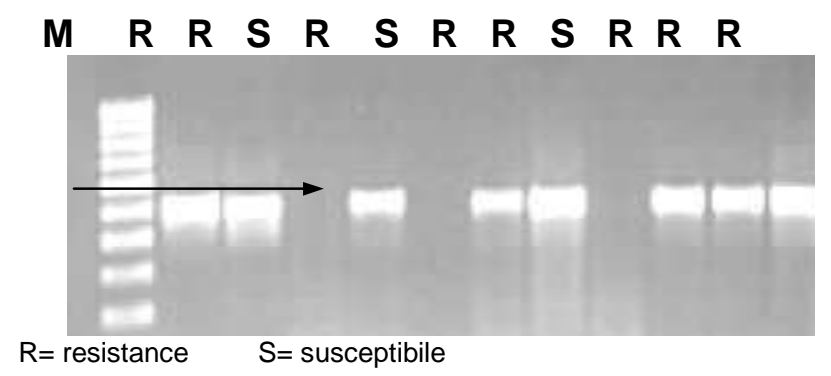

Figure 2: Amplification with marker $\mathrm{YrSTS} / 7,8$ produced of $439 \mathrm{bp}$ fragment in $\mathrm{F} 2$ resistance segregation carrier gene $\mathrm{Yr} 5$

The results PCR amplification with marker YrSTS/7,8 produced 439-bp fragment in F2 resistance segregation carry gene $Y r 5$ and did not show any amplification in F2 susceptible segregation not carry gene Yr5 (figure2). Segregation in F2 of individual which, reacted with the primer $Y r S T S / 7,8$ and shown in fig(2) in this respect, specific DNA segment of 58 individual of $\mathrm{F} 2$ have linked with primer $Y r S T S / 7,8$ 439bp band. Twenty-one of individual plants in F2 did not show any amplification to primer $Y r S T S / 7,8$, therefore, the status of $Y r 10$ gene in these individual plants. This result reveled that the resistance: susceptible individuals are 58:21 with expected ratio 3:1 which verified by $\mathrm{X}^{2}$. The results of current study suggest that transfer by crosses Yr5 could be one of the genes responsible for the resistance.

\section{DISCUSSION}

Yellow rust is one of the most aggressive diseases on common wheat Triticum aestivum worldwide. In the Egypt, the north country are the most affected, although is becoming more important in the country . Stripe rust is caused by the fungus Puccinia striiformis. $f$. sp. tritici Eriks. The preferred way of controlling the disease is through the use of resistant cultivars. There are many genes that can express resistance to this disease. However, changes in pathogen virulence can render them useless for breeding after period of time. Most of the Egyptian cultivars exhibited considerable level of susceptibility, with 
few exception El-Dauodi et al. (1998).

Results studied five ten crosses to stripe rust infection at seedling stage under greenhouse condition, the infection types of $F_{1}$ plants indicated that the five ten tested crosses having Yr5, Yr10 and Yr15 it's resistant. As well as, $F_{2}$ segregation of crosses having Yr5, Yr10 and Yr15 confirmed the results of $F_{1}$ and indicated that resistance was dominant over susceptibility. At adult stage Yr5, Yr10 and $Y r 15$ and its crosses with tested, $\left(F_{1}\right)$, exhibited high resistance. The rest of tested parents showed different degrees of susceptibility. Conversely $\mathrm{F}_{2}$ segregations of crosses having Yr5, Yr10 and Yr15 showed that resistance was dominant over susceptibility. Also, results indicated that crosses fitted the expected ratio 3:1. This ratio verified that single dominant gene pair controls stripe rust resistance and supported the F-i result at seedling and adult stages. This data similarly results (Tokubayeva and Shulembaeva 2012), The population analysis of $\mathrm{F} 1$ hybrids received from crossings of I-344 and I-345 lines with the lines carrying effective $\mathrm{Yr}$ genes all the hybrids F1 showed dominant character of inheritance for the resistance. . In F2 progeny analysis showed that the ratio of resistant and susceptible plants, resistance was dominant over susceptibility in these crosses, with expected ratio 3:1. (Li et al. 2011) Report that the adult plants of 103 F2 progeny were tested in the field under the natural infection of $P$. striiformis $f$. sp. tritici. Seedlings of the parents and F2 were tested with races PST of the pathogen under controlled greenhouse conditions. The genetic study showed that (PI 181434), Yr45 has a single dominant gene conferring all-stage resistance. (Zhang et al. 2010). They screened 442 F2 plants derived from two crosses between Shaanmai 139, (YrSM139) and two susceptible cultivars .In F2 progeny analysis showed that the ratio of resistant and susceptible plants, resistance was dominant over susceptibility in these crosses. Using the molecular marker method, Yr10 In this study, we used the primer Xpsp3000 to identify markers linked to yellow rust resistance genes, in this respect, specific DNA segment of 52 individual of F2 have linked with primer Xpsp3000 260-bp band. The rest 18 individuals did not linked with the primer Xpsp3000. Segregation in F2 of individual which, reacted with the primer YrSTS/7, 8 and shown in this respect, specific DNA segment of 58 individual of F2 have linked with primer YrSTS/7, 8 439-bp band. The rest 21, individuals did not link with the primer YrSTS/7, 8. ( Bariana et al. 2002), (Chen et al. 2003), (Yan et al. 2003), (Zahra et al. 2014), When the molecular markers with the primers YrSTS/7,8 and Xpsp3000 were used to detect $Y r 5$ and $Y r 10$, the targeted bands were only observed in entries genotype carry Yr5 and Yr10 genes and none in the entries not carry these genes. 
This work could be usefully applicable in the breeding wheat program against rust disease in general and stripe rust in particular under Egyptian conditions.

\section{REFERENCES}

Bariana, H. S.; G. N. Brown; N. U. Ahmed., S. Khatkar., R. L. Conner and C. R.Wellings (2002): Characterisation of Triticum vaviloviiderived stripe rust resistance using genetic, cytogenetic and molecular analyses and its marker-assisted selection. Theor. Appl. Genet, 104: 315-320.

Chague, V., T. Fahima., A. Dahan., G.L. Sun., A.B. Korol., Y.I. Ronin., A. Grama., M.S. Röder., E. Nevo (1999) : Isolation of microsatellite and RAPD markers flanking the Yr15 gene of wheat using NILs and bulked segregant analysis. Genome 42: 1050-1056.

Chen, X.; M.A. Soria; G. Yan; J. Sun and J. Dubcovsky (2003): Development of sequence tagged site and cleaved amplified polymorphic sequence markers for wheat stripe rust resistance gene Yr5. Crop Sci., 43:2058-2064.

Chen, X. M. (2005): Epidemiology and control of stripe rust [Puccinia striiformis f. sp. tritici] on wheat. Can. J. Plant Pathol., 273, 314337

Cheng, P. and X.M. Chen (2010): Molecular mapping of a gene for stripe rust resistance in spring wheat cultivar IDO377s. Theor Appl Genet., 121:195-204

El-Daoudi, Y.H.; Ikhlas, S. Shenoda; Enayat, H. Ghaenm; S.A. Abu ElNaga; R.A. Mitheces; S. Sherif; M.M. Khlalifa; and A.A. Bassiouni (1996): Stripe rust occurrence in Egypt and assessment of grain yield loss in 1995. Proceeding du symposium regional sur les maladies desceneals et deslegummuneuses alimentaries 11-14 Nov; Rabat, Maroc, pp. 341-351.

El-Daoudi; Y.H. (1998): Wheat stripe rust manamgent, considering pathotype, dynamics, identified host resistance genes and the economic threshold of controlling the disease. Annual Repot $1997 / 1998$

Gerechter-Amitai, Z.K. and R.W. Stubbs ( 1970 ): A valuable source of yellow rust resistance in Israeli population of wild emmer Triticum dicoccoides Koern. Euphytica, 19:12-21.

Gerechter-Amitai, Z. K. and A. Grama ( 1974 ): Inheritance of resistance to stripe rust (Puccinia striiformmis) in crosses between wild emmer (Triticum dicoccoides) and cultivated tetraploid and hexaploid wheat. I. Triticum durum. Euphytica, 23:387-392.

Gerechter-Amitai, Z . K; C. H .Van Silfhout; A. Grama; and F. Kleitman (1989) . Yr15 a new gene for resistance to Puccinia striiformis in Triticum dicoccoides sel. G-25. Euphytica, 43: 187-190. 
Kaur, N., K. Street; M. Mackay; N .Yahiaoui; B. Keller ( 2008): Molecular approaches for characterization and use of natural disease resistance in wheat. Eur. J. Plant Pathol., 121: 387-397.

Kema, G.H.J (1992): Resistance in spelt wheat to yellow rust I. Formal analysis and variation for gliadin patterns. Euphytica, 63:207-217.

Lagudah, E.S (2011) . Molecular genetics of race non-specific rust resistance in wheat. Euphytica,179: 81-91.

Law, C.N (1976) : Genetic control of yellow rust resistance in T. spelta album. Plant Breeding Institute, Cambridge, Annual Report 1975, 1976: 108-109.

Li,Q; X.M. Chen; M.N. Wang, and J. X. Jing (2011). Yr45, a new wheat gene for stripe rust resistance on the long arm of chromosome 3D. Theoretical and Applied Genetics.2011, 122, 189-197

Liu, X. K. (1988): A preliminary study on the inheritance of resistance to stripe rust in wheat. Acta Phytophyl. Sin., $15:$ 33-39.

Macer, R.C.F (1966): The formal and monosomic genetic analysis of stripe rust (Puccinia striiformis) resistance in wheat. IJ. Mackey (ed.) Proc. of 2nd Int. Wheat Genet. Symp. Lund, Sweden 1963. Hereditas Suppl., 2:127-142

Ma J., Zhou R., Y. Dong., L .Wang., X. Wang and J. Jia( 2001): Molecular mapping and detection of the yellow rust resistance gene Yr26 in wheat transferred from Triticum turgidum $\mathrm{L}$. using microsatellite markers. Euphytica 120, 219-226.

McIntosh, R.A., J. Silk and T.T. The. (1996): Cytogenetic studies in wheat XVII Monosomic analysis and linkage relationships of gene Yr15 for resistance to stripe rust. Euphytica 89: 395-399

McIntosh R. A ; E.S. Lagudah (2000): Cytogenetical studies in wheat. XVIII. Gene Yr24 for resistance to stripe rust. Plant Breed, 119:8183

McIntosh, R.A., K.M. Devos., J. Dubcovsky., W.J. Rogers., C.F. Morris., R. Appels and O.A. Anderson (2005): Catalogue of gene symbols for wheat. Annu. Wheat Newsl., 51: 250-285.

McIntosh, R. A., J. Dubcovsky., W. J. Rogers., C. Morris., R. Appels and X. C. Xia (2009): Catalogue of gene symbols for wheat: 2009 supplement.

(2010-8-12).

http://www.shigen.nig.ac.jp/wheat/komugi/genes/macgene/supple ment2009.pdf

McNeal, F.H; C.F. Konzak; E.P. Smith; W.S. Tate and T.S. Russell (1971): A uniform system for recording and processing cereal data. Agricultural Research Service Bulletin 34-121. (U.S. Dept of Agriculture: Washington) 34.121,42pp25.

Peng, J.H; T. Fahima., M.S. Röder and Q.Y. Huang ( 2000): High density molecular map of chromosome region harboring stripe rust resistance genes YrH52 and Yr15 derived from wild Emmer wheat Triticum dicoccoides. Genetica. , 109:199-210.

Prasad, M., N. Kumar., P.L . Kulwal., M.S. Röder., H.S. Balyan., H.S. Dhaliwal, and P.K. Gupta (2003): QTL analysis for grain protein 
content using SSR markers and validation studies using NILs in bread wheat. Theor. Appl. Genet. 106:659-667.

Robert, O., F. Dedryver., M. Leconte., B. Rolland., and C. VallavieillePope, (2000): Combination of resistance tests and molecular tests to postulate the yellow rust resistance gene Yr17 in bread wheat lines. Plant Breeding, 119: 467-472.

Smith, P., R. Koebner and L. Boyd (. 2003): The development of a STS marker linked to a yellow rust resistance derived from the wheat cultivar Moro. Theor Appl Genet.,104:1278- 1282

Steel, R.D. and T.H. Torrie (1960). Principles and procedures of statistic: Mc-Grow-Hill, N.Y., USA.

Stubbs, R. W. (1988): Pathogenicity analysis of yellow (stripe) rust of wheat and its significance in a global context. In Breeding strategies for resistance to the rusts of wheat (ed. N.W. Simmonds and S. Rajiaram), pp. 23-28. CIMMYT, Mexico.

Sun, Q., Y. Wei., C. Ni., C. Xie and T. Yang (2002). Microsatellite marker for yellow rust resistance gene Yr5 introgressed from spelt wheat. Plant Breed. 121:539-541.

Tokubayeva, A.A., and K.K. Shulembaeva (2012): Genetic identifi cation of wheat resistance genes to yellow rust. International Journal of Biology and Chemistry, $4: 3-12$

Wang, X., W. Zheng., H. Buchenauer., J. Zhao., Q. Han., L. Huang and Z. Kang (2008): The development of a PCR-based method for detecting Puccinia striiformis latent infections in wheat leaves. Eur. J. Plant Pathol., 120:241-247.

Yan, G.P., X.M. Chen., R.F. Line and C.R. dwellings (2003): Resistance gene analog polymorphism markers co-segregating with the Yr5 gene for resistance to wheat stripe rust have homology with plant disease resistance genes. Theoretical and Applied Genetics, 106:636-643

Zhang, H ., R.E.N .Zhi-Long., H .U .Yin-Gang., W.A. Chang-You and J.I. Wan-Quan (2010): Characterization of Wheat Stripe Rust Resistance Genes in Shaanmai 139. Acta Agronmica cinica. ,36: 109-114

Zahra ,P., D. Ali., N . Ali ., H. Bahram And E . Esmaeil (2014): Identification of wheat stripe rust resistance genes in Iranian wheat Cultivars using molecular markers. Annual Research and Review in Biology., 17:2766-2778 


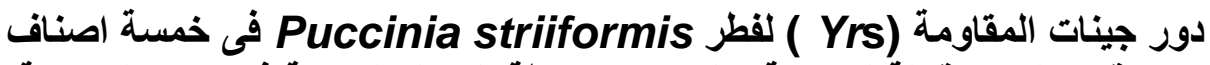
من قمح الخبز قابلة للاصابة والتحقى بواسطة الدلائل الجزئية فى تقييم المقاومة فئة

عبدالعزيز عبدالناصر محمد ابوعلى1 و ثناء حمد عبد السلام عبد الكريم2

1- معهج بحوث أمراض النباتات ، قسم أمراض القمح ، مركز البحوث الزراعية

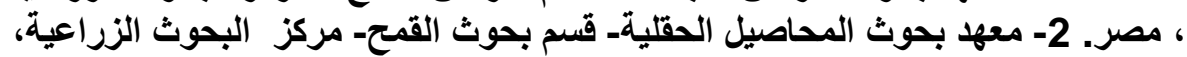
مصر

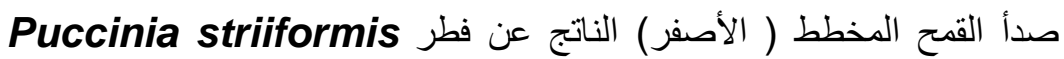
أحد أكثر الامراض المدمرة لمحصول القمح فيى العالم. ظهور سلاصل فلاتلات جديدة للمسبب

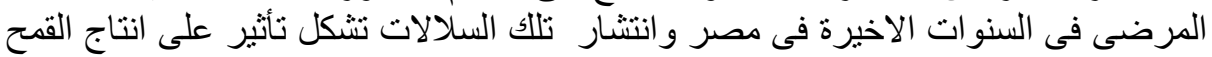

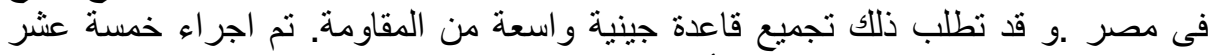

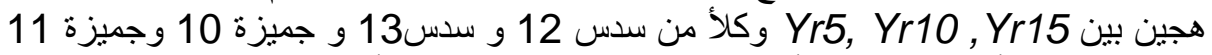

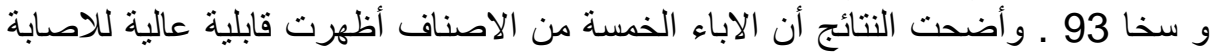

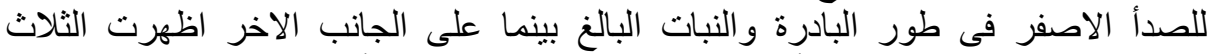

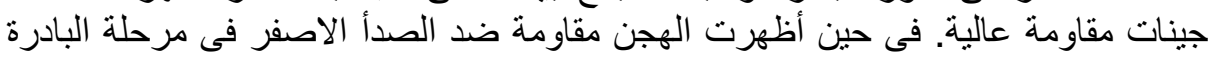

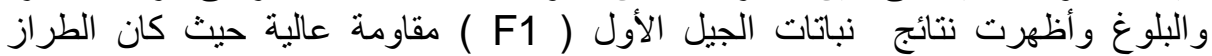

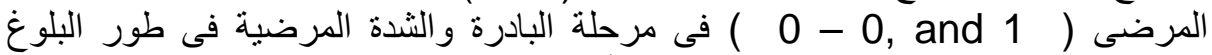

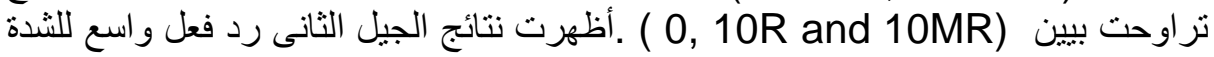

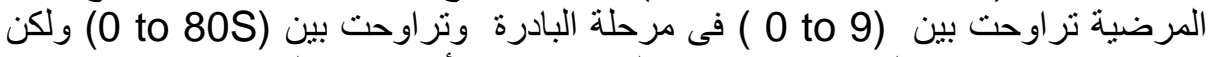

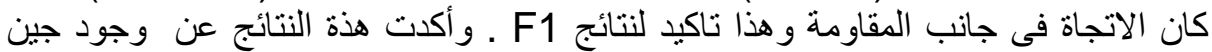

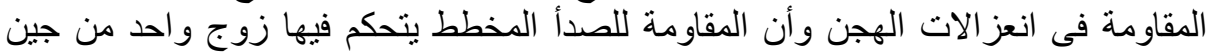

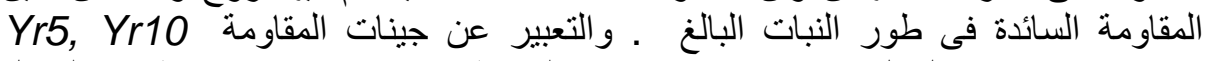

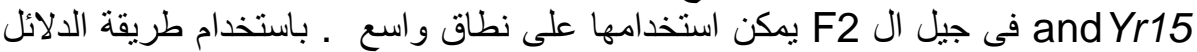

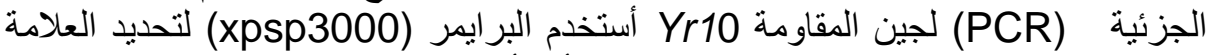

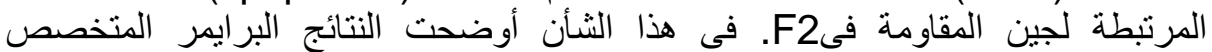
(xpsp3000)

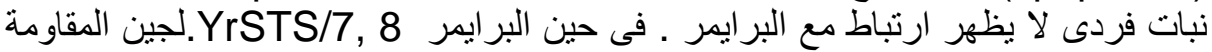

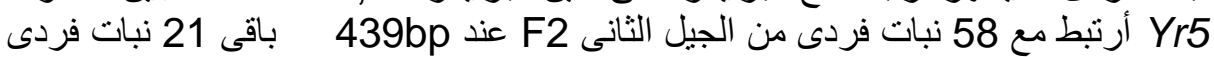

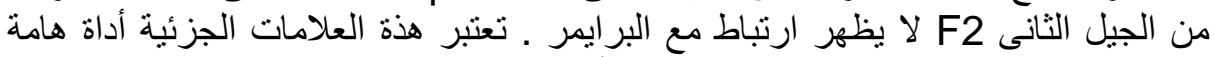
لمربى القمح فى التربية الهرمية للمقاومة للصدأ الاصفر ( المخطط) . 